that such systems are numerous) and discusses the origin of life; he tries to define the process of thinking, describes how 'thinking automata' might come to dominate the Earth and points out that such forms of 'life' would be the most likely emissaries from superior communities.

The third contribution, on multiple staging in carrier rockets, by H. E. Nylander and F. W. Hopper, is a competent and yet somewhat unsatisfactory survey, not because of any fault on the part of the authors but rather because of the subject, which although omnipresent in space technology is difficult to treat as a separate abstract topic. In the fourth article M. Tucker presents a thorough review of spacecraft entry and landing in planetary atmospheres. Ho lays most emphasis on re-entry into the Earth's atmosphere, but also discusses landings on Mars, Venus and Jupiter. Next, S. J. Gerathewohl gives an excellent account, running to more than a hundred pages, of the development of manned artificial satellites and space stations. But he evades the brutal truth that, if the space stations he describes so fully are outside the Earth's atmosphere, their crews are likely to be killed when bursts of high-energy protons are emitted from the Sun at times of major solar disturbances: he merely remarks that adequate radiation protection must be provided, without saying how. Finally, J. J. Barré provides a very detailed account of the possible role of radioactive elements as sources of energy for spacecraft propulsion, with copious data on the properties of the elements in question.

These admirable individual contributions have been well edited and printed; together, this volume and its three predecessors serve as a valuable, though as yet incomplete, encyclopædia of space science and technology.

D. G. KING-HeLE

\section{RADIOACTIVITY AND MAN'S ENVIRONMENT}

Living with the Atom

By Prof. Ritchie Calder. Pp. ix $+275+16$ plates. (Chicago and London: University of Chicago Press, 1962.) 5.95 dollars; $42 s$.

THIS book reports on two colloquia organized by the

Section of Nuclear Medicine of the Pharmacology Department of the University of Chicago in 1960. They dealt with radioisotopes in man's environment, and with public health and the problom of disposal of radioactive waste. Both discussed the present state of knowledge and uncertainty about the hazards and bonefits attending the use of radioactive materials, and also how this knowledge can be translated into public information.

The author gives his own and other people's contributions to a discussion on responsible reporting in Chapter 2. It is difficult for the reporter to stcer a course between the attractive liveliness that approaches the sensational, and the dry factual report that few will read; and it seems that the value of good science articles is slowly breaking in on proprietors. He feels that there is a fear and distrust of scientists, as people who ought to be abovo human fallibility but unforgivably err like everyone else; and he points out the dangers also of the responsibility for major decisions resting in the hands of men who do not know sufficient about science to be able to challonge with any confidence the advice that comes to them from their exports. There is something in this, although one would feel that a knowledge of men and a flair for consulting the right experts is what brings men to high office. (What keeps them there, however, is often a shrewd calculation of the limitations of the populace; and, in an ideal democracy, every voter would as a duty be reasonably knowledgeable on every issue.) It is true, certainly, that there is less understanding of scientific matters than there is of really difficult subjects like economics or bringing up children; and that this is largely due to communications.

The book itself, a really excellent piece of reporting, illustrates the problems that the journalist has to face. It describes the uses of radioisotopes, and also their effect in changing the whole of man's environment. The accounts of the ways of disposing of radioactive wastesburying, running out to sea, hopefully incorporating them in glasses, faithfully moving mountains by extruding acres of cement into underground faults, and ruefully counting the cost of using outer space as a dustbinbetween them offer so much information that $I$ found them quite exacting reading. A layman could be pardoned for wondering whether already there are curies at the bottom of his garden. Which method is the safest as regards long-term interference with the environment? What is the most practicable now? Which is the most economical? These are the questions that everyone ought to know enough at least to ask. The book includes accounts of the hazards of uranium mining, and of life in a nuclear submarine. It should serve to spread the author's sound common-sense attitude towards the problems of nuclear radiation, as well as the facts brought out in the colloquia.

G. R. NoAkES

\section{PROGRESS IN OCEANOGRAPHY}

\section{The Sea}

Ideas and Observations on Progress in the Study of the Seas. General Editor: M. N. Hill. Vol. 1: Physical Oceanography. Pp. xv +864. (New York and London: Interscionce Publishers, a Division of John Wiley and Sons, Inc., 1962.) 188s.

HIS is the first of three volumes reviewing the achievements of the past twenty years in understanding the physical, chemical and geological processes in and below the oceans. The first volume, covering the major fields of physical oceanography, illustrates the vast oxpansion which has taken place in these subjects since the publication of The Oceans by Sverdrup, Johnson and Fleming in 1942 .

Articles by thirty-three contributors cover the physical properties and equations of motion of sea-water, smallscale and large-scale interactions botween the sea and the atmosphere, dynamics of currents, transmission of sound, light and other eloctromagnetic radiation, various types of wave motion, and turbulenco. Wave motions aro reviewed in articles on ripples, statistics and dynamics of wind waves, microseisms, internal waves, long waves, tides, surges and long-term variations in sea-level.

The editors are to be commended on achieving a satisfactory balance between the many rival claims on the space available. In spite of this wide coverage there remain some topics that could usefully have boen expanded. such as recont work on current systems, wind-wave generation, coastal processes and ship-wave interactions. It must be remombered that significant progress has been made in some of these fields, such as non-linear interactions, since the time of writing (December 1959-October 1960).

Some contributors succe日d in providing particularly timoly and valuable reviews of thoir subjocts. Among these must be mentioned Groen and Groves on "Surges", Hansen on "Tides", including recent storm surge computations for the North Sea, Lafond and Cox on "Internal Waves", reviewing the latest measuring techniques such as the isotherm follower and providing much now information on internal waves and their correlation with surface slicks.

The most notable contribution (and longest, 214 pages) is the review of large-scale air-sea interactions by Joanne 